Annals of Plant and Soil Research 23(3): 375-378 (2021)

https://doi.org/10.47815/apsr.2021.10087

\title{
Characterization of chrysanthemum (Dendranthema grandiflora Tzvelev) genotypes for growth, flowering characters and yield
}

\author{
SONIA SINGH ${ }^{1}$ AND A.K. GODARA ${ }^{2}$
}

\author{
${ }^{1}$ College of Horticulture, Maharana Partap Horticultural University, Karnal (Haryana) \\ Received: April, 2021; Revised accepted: May, 2021
}

\begin{abstract}
The study was carried out on thirty genotypes of Chrysanthemum at CCS Haryana Agricultural University, Hisar during 2019 and 2020 to characterize for growth, flowering characters and yield. The results revealed that maximum days to first flower bud were recorded in genotype Bicolor Aruba (62.1 and 62.2) and minimum in Orange Dazzle (51.5 and 50.7 days). Minimum days to first flower opening were recorded in Pusa Sona (68.6 and 63.8) while maximum in Star white (94.9 and 95.3 days). Maximum duration of flowering was observed in Star Yellow (84.0 and 82.9) while minimum in Pusa Aditya (25.0 and 24.9). Pusa Chitraksha recorded maximum (189.3 and 186.76) number of buds per plant and minimum in Orange Dazzle (14.7 and 13.6). Number of flowers per plant was recorded maximum in Pusa Chitraksha (174.8 and 172.5) and minimum in Golden Beauty (10.1 and 10.4). Size of flower was exhibited maximum in Star White (11.1 and 11.2) and minimum in Green Button Lorenzo (3.2 and 3.0). Flower yield/plant was found maximum in Pusa Guldata (311.7 and 289.3g) and minimum in Bicolor Aruba (12.0 and 10.9g). Flower yield was found maximum in Pusa Guldata (25.98 and $24.11 \mathrm{tha}^{-1}$ ) and minimum in Bicolor Aruba (10.03 and $9.04 \mathrm{t} \mathrm{ha}^{-1}$ ) during 2019 and 2020 respectively. Pusa Guldata genotype performed best in respect of flower yield.
\end{abstract}

Key words: Chrysanthemum, genotypes, flowering characters

\section{INTRODUCTION}

This Chrysanthemum (Dendranthema grandiflora Tzvelev) known as Guldaudi and ranks second after rose cut flower trade and fifth as pot plant (Negi et al., 2015). Chrysanthemum is very popular flower crop for using in exhibitions as cut flowers, pot mums and borders. It is very popular as loose flower, and is used for making veni, garlands, bouquets and also for offering to God for worship. The Spray varieties are used in raising flower bed, edging, mixed borders, hanging baskets, pot plants, front row planting and window boxes. This flower owns various colors likepink, white, lavender, yellow, bronze, orange, salmon red and shapes and designs like spider, quilled, pompon, anemone. Chrysanthemum is very attractive and beautiful flowering plant, having many varieties in the world (Joshi et al., 2010). The flower yield and flower quality are primarily varietal traits, but climate has also a huge impact. The performance of the genotype varies with the region, season and other growing conditions (Singh et al., 2017). There are many cultivars exhibiting wide range of variation in shape, size, colour of bloom and growing habit, which make it suitable for every purpose. In chrysanthemum, plant growth characters and floral characters are helpful in the identification of the genotypes. The flower yield capacity of a plant is very much influenced by the variation in these attributes. The fundamental role played by breeders in developing cultivars more adapted to newer techniques and patterns is largely responsible for the significant increase in demand for chrysanthemum as a pot plant and cut flower crop.

In chrysanthemum, hybridising and inducing mutations were responsible for expanding the genetic divide, resulting in a variety of plant types and new colour forms. The key research activities included the characterization of germplasm and enrichment and their use in breeding programmes, the creation of new and novel varieties through selection, hybridization, in vitro and in vivo in mutagenesis, disease management, postharvest physiology, programmed blooming, molecular techniques, tissue culture and to standardized agro-techniques (Datta 2015). Looking at the importance and commercial potential there is an urgent need to conserve and characterize the available variability, its evolution and to identify potential genotypes. The present study was designed to study growth, flowering and yield attributing characters in various genotypes of chrysanthemum. 


\section{MATERIALS AND METHODS}

The study was conducted on thirty genotypes of Chrysanthemum at CCS Haryana Agricultural University, Hisar situated at 29 $10^{\prime}$ North latitude and $75^{\circ} 46^{\prime}$ East longitude with an elevation of 215.2 meters above Mean Sea Level during 2019 and 2020. Hisar is characterized by semi-arid climate with hot and dry summer and cold winter. The experiment was conducted in randomized block design with three replications. The sowing was done in $1.5 \mathrm{~m}$ $x 1.5 \mathrm{~m}$ plot size with $30 \mathrm{~cm} \times 30 \mathrm{~cm}$ spacing. The soil of the experimental site was alkaline $(\mathrm{pH}$ 8.5) having $5.1 \mathrm{gkg}^{-1}$ organic carbon and $130 \mathrm{~kg}$ available nitrogen ha ${ }^{-1}$. Well rotten farmyard manure@ @ kg/m ${ }^{2}$ was uniformly mixed as a basal dose in the soil a fortnight before transplanting of seedling. The fertilizers were applied @ 10: 8: $8 \mathrm{~g} \mathrm{~m}^{-2}$ of nitrogen, phosphorus and potassium. Half quantity of nitrogen and full phosphorus and potassium was applied before transplanting while the remaining half dose of nitrogen was applied after one month transplanting. The observations on days taken to first flower bud, days taken to first flower opening, duration of flowering (days), number of buds per plant, number of flowers per plant, flower diameter $(\mathrm{cm})$, flower yield per plant, flower yield per hectare were recorded. The data obtained on various characters were subjected to statistical analysis in accordance with Panse and Sukhatme (1995).

\section{RESULTS AND DISCUSSION}

The results revealed that significant variation existed among the genotypes for all the characters studied. Maximum days to first flower bud were recorded in genotype Bicolor Aruba (62.1 and 62.2) and minimum were recorded in Orange Dazzle (51.5 and 50.7 days) during 2019 and 2020, respectively (Table1).

Table 1: Growth and flower characters in various genotypes of Chrysanthemum

\begin{tabular}{|c|c|c|c|c|c|c|c|c|}
\hline \multirow[t]{2}{*}{ Genotypes } & \multicolumn{2}{|c|}{$\begin{array}{l}\text { Days taken to } \\
\text { initiation first bud }\end{array}$} & \multicolumn{2}{|c|}{$\begin{array}{l}\text { Days taken to opening } \\
\text { first flower }\end{array}$} & \multicolumn{2}{|c|}{$\begin{array}{c}\text { Duration of flowering } \\
\text { (Days) }\end{array}$} & \multicolumn{2}{|c|}{$\begin{array}{l}\text { Flower diameter } \\
(\mathrm{cm})\end{array}$} \\
\hline & 2019 & 2020 & 2019 & 2020 & 2019 & 2020 & 2019 & 2020 \\
\hline Pusa Sona & 57.9 & 53.3 & 68.6 & 63.8 & 66.0 & 62.1 & 4.0 & 3.1 \\
\hline Star Yellow & 59.5 & 55.8 & 71.9 & 72.8 & 84.0 & 82.9 & 8.8 & 8.1 \\
\hline Pusa Centnary & 61.3 & 58.2 & 88.3 & 87.7 & 58.4 & 57.0 & 9.1 & 8.7 \\
\hline Thichen Queen & 57.5 & 53.8 & 83.3 & 81.7 & 72.7 & 73.0 & 9.6 & 9.0 \\
\hline Pusa Guldata & 58.8 & 60.2 & 81.7 & 83.5 & 63.5 & 61.9 & 4.4 & 4.0 \\
\hline Star White & 61.9 & 62.7 & 94.9 & 95.3 & 49.1 & 46.8 & 11.1 & 11.2 \\
\hline Pusa Shwet & 61.9 & 57.9 & 91.7 & 93.8 & 52.0 & 53.0 & 8.6 & 8.1 \\
\hline Pusa Aditya & 60.9 & 60.9 & 84.7 & 81.4 & 25.0 & 24.9 & 6.1 & 5.9 \\
\hline Tata Century & 60.3 & 59.5 & 82.4 & 82.9 & 59.7 & 58.1 & 11.0 & 11.1 \\
\hline Pusa Chitrksha & 60.3 & 58.0 & 85.7 & 83.2 & 41.0 & 40.6 & 5.0 & 4.7 \\
\hline White Gadget & 58.7 & 52.1 & 78.9 & 75.3 & 60.1 & 57.3 & 4.0 & 4.1 \\
\hline Bicolor Aruba & 62.3 & 62.1 & 90.5 & 85.9 & 48.0 & 47.5 & 5.5 & 5.2 \\
\hline Ping Pong Yellow & 52.5 & 54.6 & 79.1 & 79.8 & 38.5 & 38.2 & 4.5 & 4.2 \\
\hline Red Borolo & 57.8 & 56.5 & 79.0 & 78.1 & 61.0 & 57.6 & 6.1 & 6.0 \\
\hline Orange Dazzle & 51.5 & 50. & 70.9 & 68.9 & 59.0 & 57.2 & 6.7 & 6.5 \\
\hline Pink Sensation & 59.5 & 57.8 & 80.9 & 80.6 & 31.0 & 30.9 & 5.0 & 5.2 \\
\hline Potenza Pink & 57.5 & 57.7 & 84.1 & 85.9 & 40.0 & 40.7 & 5.1 & 4.9 \\
\hline Purple Lima & 56.1 & 55.9 & 76.9 & 76.8 & 69.3 & 67.5 & 6.3 & 6.3 \\
\hline Papaya Clever & 56.2 & 58.3 & 88.3 & 91.3 & 42.5 & 43.8 & 7.5 & 7.1 \\
\hline Green Button Lorenzo & 54.9 & 53.3 & 77.8 & 73.4 & 50.8 & 52.8 & 3.2 & 3.0 \\
\hline Classic Beauty & 60.2 & 61.7 & 85.1 & 88.4 & 59.4 & 67.6 & 5.9 & 5.3 \\
\hline Biscuit Parcel & 56.0 & 61.3 & 86.3 & 89.4 & 41.1 & 42.8 & 4.3 & 4.0 \\
\hline Pink cloud & 55.4 & 53.2 & 81.5 & 77.8 & 73.0 & 72.5 & 6.0 & 5.9 \\
\hline Haldighati & 56.5 & 62.1 & 89.3 & 91.4 & 59.9 & 63.2 & 4.3 & 4.1 \\
\hline HYDC 12 & 56.9 & 58.4 & 82.9 & 78.1 & 39.3 & 38.4 & 5.8 & 5.2 \\
\hline Bright yellow & 57.1 & 60.5 & 84.7 & 85.8 & 29.5 & 27.5 & 6.6 & 6.2 \\
\hline Red Glamour & 58.5 & 52.5 & 92.0 & 92.9 & 47.7 & 49.0 & 5.5 & 5.3 \\
\hline Mayur & 57.5 & 51.2 & 93.6 & 96.3 & 34.7 & 35.0 & 6.9 & 7.0 \\
\hline Golden Splendor & 57.1 & 62.5 & 94.1 & 92.1 & 48.0 & 48.1 & 6.0 & 5.9 \\
\hline Garden Beauty & 54.9 & 51.8 & 92.2 & 93.1 & 28.8 & 29.5 & 8.7 & 8.5 \\
\hline C.D. $(P=0.05)$ & 0.73 & 4.21 & 1.09 & 3.87 & 1.99 & 3.11 & 0.30 & 0.34 \\
\hline
\end{tabular}


Minimum days to first flower opening were recorded in Pusa Sona (68.6 and 63.8) and maximum in Star white (94.9 and 95.3 days) during 2019 and 2020 respectively. Maximum duration of flowering was observed in Star Yellow (84.0 and 82.9) while minimum in Pusa Aditya (25.0 and 24.9) during 2019 and 2020 respectively. Maximum size of flowers were exhibited in genotype Star White (11.1 and 11.2) and minimum in Green Button Lorenzo (3.2 and 3.0). Number of buds per plant was recorded maximum in Pusa Chitraksha (189.3 and 186.7) and minimum in Orange Dazzle (14.7 and 13.6). Similarly, number of flowers per plant was recorded maximum in Pusa Chitraksha (174.8 and 172.5) and minimum in Golden Beauty (10.1 and 10.4). These variations in growth and flower characters may be attributed to genetic makeup of genotypes (Singh et al., 2017, Negi et al., 2019). Flower yield/plant was recorded maximum in Pusa Guldata (311.7 and 289.3g) and minimum was observed in Bicolor Aruba (12.0 and $10.9 \mathrm{~g})$. Flower yield/hectare was found maximum in Pusa Guldata (25.98 and $24.11 \mathrm{t}$ ha $\left.{ }^{1}\right)$ and minimum was in Bicolor Aruba (10.04 and $9.04 \mathrm{t} \mathrm{ha}^{-1}$ ) during 2019 and 2020, respectively (Table 2).

Table 2: Buds per plant, flowers per plant, fresh weight of 10 flowers and dry weight of 10 flowers in various genotypes of Chrysanthemum

\begin{tabular}{|c|c|c|c|c|c|c|c|c|}
\hline \multirow{2}{*}{ Genotypes } & \multicolumn{2}{|c|}{ Buds per Plant } & \multicolumn{2}{|c|}{ Flowers per plant } & \multicolumn{2}{|c|}{ Flower yield per plant $(\mathrm{g})$} & \multicolumn{2}{|c|}{ Flower yield $\left(\mathrm{t} \mathrm{ha}^{-1}\right)$} \\
\hline & 2019 & 2020 & 2019 & 2020 & 2019 & 2020 & 2019 & 2020 \\
\hline Pusa Sona & 185.1 & 178.7 & 169.1 & 167.8 & 114.0 & 88.6 & 9.50 & 7.38 \\
\hline Star Yellow & 25.7 & 24.5 & 10.9 & 10.2 & 164.3 & 153.8 & 13.69 & 12.81 \\
\hline Pusa Centnary & 28.1 & 26.7 & 12.9 & 11.4 & 134.5 & 113.7 & 11.21 & 9.48 \\
\hline Thichen Queen & 22.3 & 22.8 & 12.5 & 12.9 & 149.5 & 153.5 & 12.46 & 12.79 \\
\hline Pusa Guldata & 179.0 & 178.3 & 164.8 & 162.6 & 311.7 & 289.3 & 25.98 & 24.11 \\
\hline Star White & 20.1 & 20.8 & 17.1 & 21.0 & 213.6 & 218.7 & 17.80 & 18.22 \\
\hline Pusa Shwet & 132.7 & 131.5 & 118.6 & 119.3 & 268.5 & 289.3 & 22.38 & 24.11 \\
\hline Pusa Aditya & 112.4 & 110.9 & 99.4 & 96.5 & 113.4 & 123.1 & 9.45 & 10.26 \\
\hline Tata Century & 18.3 & 15.8 & 10.5 & 10.6 & 107.1 & 98.3 & 8.93 & 8.19 \\
\hline Pusa Chitrksha & 189.3 & 186.8 & 174.8 & 172.5 & 243.8 & 229.0 & 20.32 & 19.08 \\
\hline White Gadget & 116.8 & 113.0 & 93.3 & 92.3 & 89.7 & 82.7 & 7.47 & 6.89 \\
\hline Bicolor Aruba & 18.7 & 17.5 & 14.3 & 13.2 & 12.0 & 10.9 & 10.04 & 9.04 \\
\hline Ping Pong Yellow & 16.7 & 14.7 & 11.5 & 11.4 & 71.5 & 68.7 & 5.96 & 5.73 \\
\hline Red Borolo & 26.3 & 26.2 & 21.4 & 21.8 & 32.2 & 29.1 & 2.68 & 2.42 \\
\hline Orange Dazzle & 14.7 & 13.3 & 10.5 & 11.0 & 75.8 & 79.6 & 6.31 & 6.63 \\
\hline Pink Sensation & 42.8 & 39.9 & 37.0 & 35.7 & 49.8 & 47.4 & 4.15 & 3.95 \\
\hline Potenza Pink & 29.7 & 29.2 & 20.8 & 22.0 & 45.4 & 45.9 & 3.78 & 3.83 \\
\hline Purple Lima & 37.9 & 36.9 & 22.8 & 23.5 & 139.6 & 143.1 & 11.63 & 11.93 \\
\hline Papaya Clever & 17.8 & 16.1 & 12.7 & 11.8 & 20.1 & 18.4 & 1.67 & 1.53 \\
\hline Green Button Lorenzo & 39.3 & 39.4 & 25.1 & 23.4 & 97.8 & 89.3 & 8.15 & 7.44 \\
\hline Classic Beauty & 84.2 & 81.9 & 74.5 & 73.9 & 147.0 & 138.2 & 12.25 & 11.52 \\
\hline Biscuit Parcel & 105.3 & 102.6 & 95.5 & 99.4 & 205.6 & 196.0 & 17.13 & 16.34 \\
\hline Pink cloud & 130.7 & 123.4 & 109.6 & 104.8 & 226.4 & 208.9 & 18.87 & 17.41 \\
\hline Haldighati & 59.5 & 56.5 & 49.7 & 47.4 & 87.5 & 84.7 & 7.29 & 7.057 \\
\hline HYDC 12 & 47.4 & 47.1 & 37.6 & 37.4 & 55.0 & 58.7 & 4.58 & 4.89 \\
\hline Bright yellow & 34.5 & 35.0 & 28.5 & 24.9 & 41.3 & 34.4 & 3.44 & 2.87 \\
\hline Red Glamour & 29.1 & 26.3 & 20.9 & 19.1 & 29.1 & 23.0 & 2.42 & 1.92 \\
\hline Mayur & 118.8 & 116.9 & 98.9 & 95.1 & 162.5 & 150.9 & 13.54 & 12.58 \\
\hline Golden Splendor & 25.7 & 24.7 & 19.2 & 21.1 & 34.1 & 35.8 & 2.84 & 2.98 \\
\hline Garden Beauty & 17.5 & 16.7 & 10.1 & 10.4 & 12.3 & 13.1 & 1.02 & 1.09 \\
\hline C.D. $(P=0.05)$ & 6.9 & 3.4 & 4.7 & 3.6 & 19.1 & 13.7 & 1591.5 & 1143.5 \\
\hline
\end{tabular}

Maximum days to first flower bud were recorded in genotype Bicolor Aruba while minimum in Orange Dazzle. Maximum days to first flower opening were recorded in Pusa Sona 
and minimum in Star white. This variation in duration of flowering among the genotypes may be attributed to genetic makeup of genotype, environmental influence and other management factors. The number of flowers produced per plant may be directly related to more number of branches, more plant spread and more number of leaves and accumulation of more photosynthates, thereby leading to the production of more number of flowers. Similar findings were also observed by Madam et al., (2016), Kumar et al., (2014), Banerji et al., (2012), Singh et al., (2017) and Negi et al.,

\section{REFERENCES}

Banerji, B.K., Batra, A. and Dwivedi, A.K. (2012) Morphological and biochemical characterization of chrysanthemum. Journal of Horticultural Sciences 7(1): 5155.

Datta, S. K. (2015). Indian Floriculture-Role of CSIR. Regency Publications, A Division of Astral International (P) Ltd, New Delhi.

Joshi, M., Verma, L.R. and Masu, M.M. (2010) Performance of different varieties of chrysanthemum in respect of growth, flowering and flower yield under north Gujarat condition. The Asian Journal of Horticulture 4(2): 292-294.

Kumar, S., Kumar, M., Malik, S., Singh, M.K. and Kumar, S. (2014) Evaluation of chrysanthemum (Dendranthema grandiflora Tzvelev) genotypes using morphological characters under climatic conditions of western UP. Annals of Horticulture 7(2): 162-165.

Madam, A. R., Jyothi, K.U., Vani, V.S., Reddy, A.R. and Ambati, R. (2016) Vegetative growth and flower yield as influenced by different chrysanthemum (Dendranthema grandiflora Tzvelev) cultivars in alfisols of
(2019) in chrysanthemum. Pusa Guldata, Pusa Chitrksha, Star White and Star Yellow genotypes performed well, hence, these genotypes can be selected in breeding programmes. Significant variation was observed for days taken to first bud initiation, days taken to first flower opening, duration of flowering, Flower diameter, number of buds per plant, number of flowers per plant and flower yield per plant. Similar results were also reported by Joshi et al. (2010) for number of buds per plant, number of flowers per plant and flower yield in African marigold.

coastal Andhra Pradesh. Annals of Horticulture 9(1): 21-24.

Negi, R., Dhiman, S.R. and Gupta, Y.C. (2019) Studies on growth and flowering behavior of newly evolved genotypes of Chrysanthemum (Dendranthema grandiflora Tzvelev) for loose flower production. International Journal of Current Microbiology and Applied Sciences 8(11): 341-346.

Negi, R., Jarial, K., Kumar, S. and Dhiman, S.R. (2015) Evaluation of different cultivars of chrysanthemum suitable for low hill conditions of Himachal Pradesh. Journal of Hill Agriculture 6(2): 144-146.

Panse, V.G. and Sukhatme, P.V., (1995) Statistical Methods for Agricultural Workers. ICAR, New Delhi. pp 359.

Singh, A.K., Singh, D.K., Singh, A.K. and Kumar, R., (2017) Evaluation of Different Chrysanthemum (Chrysanthemum morifolium) Genotypes under Shade Net House in Northwest Himalaya, Indian Journal of Pure \& Applied Biosciences 5(1): 980-985. 